\title{
Correspondence
}

\section{Pathways of preferential arterial conduction}

Sir,

In his reply to our earlier letter $(1985 ; 53: 350)$ it seems to us that Dr T N James has misconstrued the point we wish to make. In our letter it is clear that when we speak of the division of the ventricular bundle branches we discuss the division of all the bundle branches. The relevant sentence is "if the tissue within the insulated sheaths is divided". Here we use the plural "sheaths" and clearly refer to the entirety of the bundle branches. Dr James's comments concerning the division of an individual bundle branch are entirely appropriate. To the best of our knowledge, however, if all the bundle branches are divided (in the absence of any pathways for pre-excitation) then conduction into the ventricle does indeed cease. In other words, division of an anatomically discrete system will prevent the conduction. We restate our contention that this is not the case with the atrial myocardium; this is the point that we asked Dr James to answer.

Robert H Anderson*

Anton E Becker, $\dagger$

^Cardiothoracic Institute,

Brompton Hospital,

Fulham Road,

London SW3 6HP.

†Department of Pathology,

Academisch Medisch Centrum,

Meibergdreef 9 ,

1105 AZ Amsterdam,

The Netherlands.

\section{Notices}

\section{5 years of electrocardiology in Amsterdam}

An international symposium honouring the late Professor Dirk Durrer and sponsored by the Interuniversity Cardiology Institute in The Netherlands will be held in Amsterdam on 29 and 30 May 1986. Further information may be obtained from: Stitchting "DURRER-Comité", Secretariaat: Mevr. B. Hoogenhout, Assumburg 50, 1081 GC Amsterdam, The Netherlands.

\section{British Cardiac Society}

The Autumn Meeting will be held at the Wembley Conference Centre, London, on 26 to 28 Novcmber 1985 , and the closing date for receipt of abstracts will be 1 August 1985.

The Annual General Meeting for 1986 will take place in York on 2 and 3 April 1986, and the closing date for receipt of abstracts will be 2 January 1986 . 